\title{
Penilaian User Experience Menggunakan Metode Technology Acceptance Model (TAM) Terhadap Aplikasi Augmented Reality Gamelan Jawa
}

\author{
Sitaresmi Wahyu Handani ${ }^{\text {a,1,* }}$, Septiana Nur Hidayah ${ }^{\text {a,2 }}$ Ito Setiawan $^{3}$ \\ ${ }^{a}$ Fakultas Ilmu Komputer, Universitas Amikom Purwokerto, Jl. Letjend Pol. Soemarto, Purwokerto, Jawa Tengah, 53127, Indonesia \\ ${ }^{1}$ sita.handani@amikompurwokerto.ac.id *; ${ }^{2}$ septiananur80@gmail.com, ${ }^{3}$ itoawan@gmail.com \\ * Koresponsendi penulis
}

\section{ARTICLE INFO}

Article history

Menerima 19 Mei 2020

Revisi 1 Juni 2020

Diterima 3 Juni 2020

Kata Kunci

Art

Gamelan

Augmented Reality

Technology Acceptance Model TAM

\begin{abstract}
Gamelan is one of Indonesia's local cultures that need to be maintained. Several studies related to the familiarization of gamelan to the younger generation have been carried out, including producing applications that combine gamelan with the latest technology, namely augmented reality. The use of augmented reality technology in order to display and introduce gamelan instruments (can be found in this link: shorturl.at/hpJL1) is a new innovation and needs to be appreciated. Nevertheless, it needs a separate assessment to find out whether the use of technology has a positive impact on its users or not. Through this research, researchers conducted a deeper study using the Technology Acceptance Model (TAM) method to determine user experience in interacting with augmented reality gamelan applications. There are five aspects tested, namely Perceived Ease of Use, Perceived Usefulness, Attitude Toward Using, Behavioral Intention of Use, Actual System Usage. The results of the validity and reliability tests conducted showed that all items in the questionnaire distributed were valid and reliable. While from the analysis of descriptive data conducted, it was found that the user's perception of the five aspects mentioned above was very good with the highest score of 4.10 in the aspect of ease of use and user attitude.
\end{abstract}

This is an open access article under the CC-BY-SA 4.0 license.

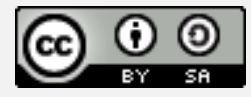

\section{Pendahuluan}

Indonesia adalah negara yang kaya akan budaya dan tradisi. Setiap wilayah di Indonesia memiliki budaya dan tradisi tersendiri yang merupakan warisan dan peninggalan dari leluhur. Beragamnya budaya dan tradisi yang dimiliki Indonesia memiliki sisi positif bagi Indonesia untuk lebih dikenal oleh masyarakat internasional. Dengan adanya keberagaman ini diharapkan mampu melestarikan serta mengembangkan nilai luhur dan dapat sebagai ciri khas yang dimiliki suatu negara yaitu Indonesia.

Kebudayaan adalah semua tingkah laku manusia dalam kehidupan yang menjadi atribut mereka. Sebagai contoh adalah keanekaragaman budaya yang dimiliki oleh Indonesia tersusun dari budaya lokal dan daerah yang berasal dari nenek moyang Indonesia. Budaya tersebut dapat diwariskan turun menurun kepada generasi muda untuk menciptakan kearifan lokal [1].

Gamelan adalah salah satu kekayaan budaya Indonesia di bidang musik. Gamelan biasanya tersusun dari beberapa instrumen seperti, gong, kenong, bonang, seruling. Gamelan sendiri sudah menjadi sebuah warisan budaya bagi bangsa Indonesia. Sehingga seni gamelan harus terus-menerus 
mencerminkan nilai-nilai dan pengetahuan tentang kebudayaan yang harus dilestarikan dari generasi ke generasi [2].

Di era globalisasi ini perkembangan teknologi informasi semakin maju, bahkan teknologi sudah berhasil merambah ke segala bidang kehidupan, salah satunya dibidang pendidikan. Menurut pembahasan yang dikemukakan oleh [2] bahwa perkembangan teknologi saat ini sudah memberikan pengaruh yang besar terhadap perkembangan media pembelajaran, yang dulu lebih banyak menggunakan cara tradisional namun sekarang bisa dilakukan dengan lebih praktis menggunakan teknologi digital.

Augmented Reality merupakan teknologi yang menggabungkan benda maya (dua dimensi atau tida dimensi) ke dalam sebuah lingkungan nyata lalu memproyeksikan benda-benda maya tersebut dalam waktu yang sama [3]. Penggunaan teknologi Augmented Reality sebagai media belajar dapat dijadikan sebagai alat untuk pengembangan alat musik tradisional yang lebih menarik, sehingga dapat menumbuhkan ketertarikan dan kreativitas dalam penggunaan alat musik tradisonal Gamelan sebagai warisan budaya nasional. Dengan teknologi Augmented Reality, akan menampilkan bentuk 3 dimensi dari alat-alat musik Gamelan agar dapat disajikan secara lebih nyata dan interaktif.

Untuk mengetahui sejauh mana pengalaman pengguna terhadap penggunaan teknologi, dalam hal ini teknologi Augmented Reality yang diintegrasikan dalam alat music gamelan, peneliti akan melakukan penelitian terhadap salah satu aplikasi gamelan berbasis Augmented Reality (aplikasi dapat diunduh pada link: shorturl.at/hpJL1) dengan menggunakan metode Technology Acceptance Model (TAM). Metode TAM merupakan salah satu metode yang dapat digunakan untuk mengukur user experience suatu aplikasi berbasis teknologi informasi [4][5].

\section{Metode Penelitian}

\subsection{Alur Penelitian}

Berikut adalah alur dari penelitian yang dilakukan:

a. Tahap Awal

1. Studi literatur

2. Pengumpulan data awal (wawancara dan observasi)

3. Identifikasi dan analisis masalah

b. Tahap Analisis Faktor-Faktor Penerimaan Gamelan AR (Model TAM)

1. Menentukan variabel penelitian

2. Menyusun instrument kuesioner

3. Menyebarkan kuesioner

4. Tabulasi data

5. Pengujian tingkat penerimaan aplikasi gamelan AR dengan metode TAM.

6. Analisis faktor-faktor tingkat penerimaan Gamelan AR melalui uji validasi, uji reliabilitas, dan uji analisis deskriptif.

c. Kesimpulan Tingkat Penerimaan dan Analisis Faktor

\subsection{Technology Acceptance Model (TAM)}

Metode yang digunakan dalam menguji aplikasi Gamelan Augmented Reality (Gamelan AR) adalah dengan menggunakan metode Technology Acceptance Model (TAM),

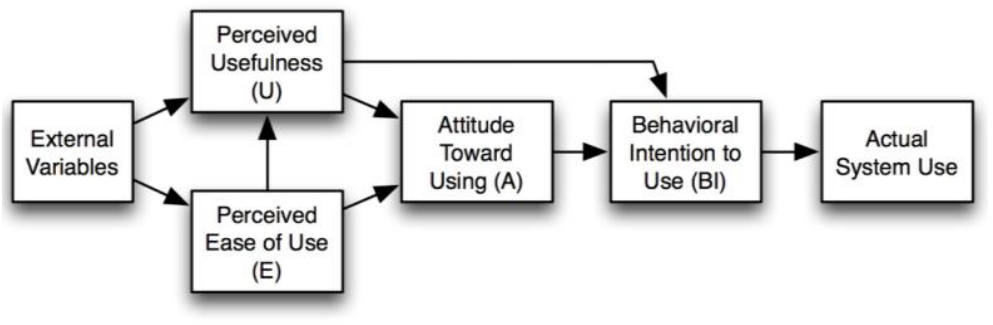

Gambar 1. Technology Acceptance Model (TAM), Davis 1989 [5] 
Faktor-faktor yang diteliti dalam penelitian ini meliputi:

a. Perceived Ease of Use, berkaitan dengan kemudahan teknologi yang dibuat dalam hal ini aplikasi gamelan berbasis Augmented Reality.

b. Perceived Usefullness, berkaitan dengan manfaat yang dapat pengguna rasakan ketika menggunakan aplikasi yang diteliti.

c. Atitude Toward Using, berkaitan dengan sikap pengguna aplikasi gamelan berbasis augmented reality.

d. Behavioral Intention of Use, berkaitan dengan penggunaan yang dilakukan secara terus menerus terhadap aplikasi yang diteliti.

e. Actual System Usage, berkaitan dengan kesadaran pengguna dalam menggunakan aplikasi tersebut dan mampu merasakan sepenuhnya manfaat dari teknologi tersebut

\section{Hasil dan Pembahasan}

\subsection{Responden}

Responden dalam penelitian ini adalah siswa kelas VIIIC SMP Negeri 5 Purwokerto. Jumlah responden berjumlah 33 siswa. Responden menjawab 20 butir pertanyaan yang sudah dipetakan sesuai dengan lima karakteristik uji TAM setelah sebelumnya masing-masing siswa menggunakan aplikasi Gamelan Augmented Reality (Gamelan AR).

\subsection{Instrument Penelitian}

Instrumen penelitian merupakan alat bantu penelitian menggunakan pengumpulan data [6]. Penelitian ini menggunakan instrument berupa kuesioner. Kuesioner berisi 20 pertanyaan terstruktur yang terbagi ke dalam lima aspek penilaian yaitu aspek kemudahan penggunaan (Perceived Ease of Use), manfaat penggunaan (Perceived Usefullness), sikap pengguna (Atitude Toward Using), keinginan pengguna (Behavioral Intention of Use), kesadaran pengguna (Actual System Usage) terhadap aplikasi Gamelan AR (Augmented Reality Gamelan).

Berikut adalah keduapuluh pertanyaan yang kami susun untuk menilai pengalaman pengguna dalam menggunakan aplikasi Gamelan AR:

Aspek Kemudahan Penggunaan (Perceived of Use):

1. Aplikasi AR Gamelan Jawa mudah digunakan

2. Aplikasi AR Gamelan Jawa tidak rumit dalam menggunakannya

3. Untuk menggunakan aplikasi AR Gamelan Jawa tidak membutuhkan keahlian khusus

4. Aplikasi AR Gamelan dapat digunakan kapan saja

5. Aplikasi AR Gamelan dapat digunakan dimana saja

Aspek Manfaat Penggunaan (Perceived Usefullness):

6. Aplikasi AR Gamelan Jawa mampu meningkatkan motivasi belajar alat musik khususnya gamelan jawa

7. Aplikasi AR Gamelan Jawa mampu meningkatkan pemahaman sata tentang alat-alat gamelan Jawa

8. Aplikasi AR Gamelan Jawa mampu meningkatkan ketrampilan saya dalam memainkan alat musik gamelan Jawa

9. Aplikasi AR Gamelan Jawa membuat saya berpikir kreatif terkait cara belajar memainkan alat musik khususnya Gamelan

Aspek Sikap Pengguna (Atitude Toward Using):

10. Saya memberikan reaksi positif terhadap inovasi AR Gamelan

11. Saya merasa senang mempelajari alat musik gamelan melalui aplikasi AR Gamelan Jawa Aspek Keinginan Penggunaan (Behavioral Intention of Use): 
12. Saya berusaha menggunakan aplikasi AR Gamelan Jawa untuk meningkatkan ketrampilan saya yang berhubungan dengan alat musik

13. Saya menggunakan aplikasi AR Gamelan Jawa ini untuk mendapatkan manfaat yang lebih

14. Saya berencana menggunakan aplikasi AR Gamelan Jawa di kemudian hari

15. Saya berniat untuk terus menggunakan aplikasi AR Gamelan Jawa

16. Saya berharap penggunaan aplikasi AR Gamelan Jawa akan terus berlanjut di waktu yang akan datang.

Aspek Kesadaran Pengguna (Actual System Usage):

17. Saya menggunakan aplikasi AR Gamelan Jawa di seolah maupun di rumah dan di tempat lain

18. Ketika ada mata pelajaran kesenian tentang gamelan, saya menyempatkan untuk menggunakan aplikasi AR Gamelan Jawa

19. Secara keseluruhan saya puas belajar dengan menggunakan aplikasi AR Gamelan Jawa

20. Saya menyampaikan kepuasan penggunaan aplikasi AR Gamelan Jawa ini kepada sesama rekan pelajar.

Responden kemudian menjawab keduapuluh pernyataan tersebut dengan checklist Sangat Setuju (SS), Setuju (S), Tidak Setuju (TS), dan Sangat Tidak Setuju (STS).

\subsection{Uji Instrumen}

\section{Uji Validitas}

Validitas adalah ukuran yang menunjukkan tingkat kevalidan atau kesahihan suatu instrumen. Instrumen dikatakan valid apabila Instrumen tersebut dapat melakukan apa yang seharusnya dilakukan dan mengukur apa yang harus diukur [7]. Uji validitas digunakan untuk mengetahui tingkat kesahihan setiap butir pertanyaan dalam angket atau kuesioner. Kuesioner yang baik harus dapat berfungsi sebagai alat pengumpul data yang tepat dan akurat. Uji validitas dilakukan terhadap seluruh butir pertanyaan dalam instrumen, yaitu dengan cara mengkorelasikan skor setiap butir dengan skor total melalui teknik Pearson Correlation (PC). Nilai PC yang didapati akan dibandingkan dengan nilai R-tabel, dimana jika nilai PC lebih besar dari R-tabel ( $\mathrm{PC}>\mathrm{Rr}$-table) maka butir pertanyaan tersebut dianggap valid [8]. RTabel untuk N(33) dengan nilai Signifikansi 5\% adalah 0.344 .

\section{Uji Reliabilitas}

Suatu alat pengukuran dikatakan realiabel apabila mendapatkan hasil yang tetap sama dari gejala pengukuran yang tidak berubah yang dilakukan pada waktu yang berbeda. Instrumen dikatakan reliable apabila dipergunakan beberapa kali untuk mengukur objek yang sama dalam waktu yang berbeda akan menghasilkan data yang sama. Reliabilitas adalah indeks yang menunjukkan sejauhmana suatu alat pengukur dapat dipercaya atau dapat diandalkan [9][10]. Dengan kata lain, realibilitas menunjukkan konsistensi dan stabilitas dari suatu skala pengukuran dengan menggunakan nilai Croncbach Alpha pada hasil analisis [8].

\subsection{Hasil Uji Validitas}

\section{Perceived Ease of Use}

Hasil uji aspek Perceived Ease of Use tersaji pada table berikut ini: 
Tabel 1. Uji Validitas Perceived Ease of Use

\begin{tabular}{|c|c|c|c|c|c|c|c|}
\hline \multicolumn{8}{|c|}{ Correlations } \\
\hline & & $x_{1}$ & $\times 2$ & $\mathrm{X} 3$ & $\mathrm{X} 4$ & $\times 5$ & TotalPEU \\
\hline \multirow[t]{3}{*}{$\mathrm{X} 1$} & Pearson Correlation & 1 & $.410^{\pi}$ & $.520^{\mathrm{N}}$ & -.084 & .097 & $.546^{\Uparrow N}$ \\
\hline & Sig. (2-tailed) & & .018 & .002 & .644 & .590 & .001 \\
\hline & $N$ & 33 & 33 & 33 & 33 & 33 & 33 \\
\hline \multirow[t]{3}{*}{$\times 2$} & Pearson Correlation & $.410^{x}$ & 1 & .314 & .025 & -.073 & $.459^{\mathrm{N}}$ \\
\hline & Sig. (2-tailed) & .018 & & .076 & .888 & .688 & .007 \\
\hline & $\mathrm{N}$ & 33 & 33 & 33 & 33 & 33 & 33 \\
\hline \multirow[t]{3}{*}{$\times 3$} & Pearson Correlation & $.520^{\mathrm{N}}$ & .314 & 1 & .311 & $.411^{\pi}$ & $.795^{\mathrm{N}}$ \\
\hline & Sig. (2-tailed) & .002 & .076 & & .079 & .018 & .000 \\
\hline & $\mathrm{N}$ & 33 & 33 & 33 & 33 & 33 & 33 \\
\hline \multirow[t]{3}{*}{$\mathrm{X} 4$} & Pearson Correlation & -.084 & .025 & .311 & 1 & $.880^{\mathrm{x}}$ & $.694^{\mathrm{N}}$ \\
\hline & Sig. (2-tailed) & .644 & .888 & .079 & & .000 & .000 \\
\hline & $\mathrm{N}$ & 33 & 33 & 33 & 33 & 33 & 33 \\
\hline \multirow[t]{3}{*}{$\times 5$} & Pearson Correlation & .097 & -.073 & $.411^{\star}$ & $.880^{\star \star}$ & 1 & $.754^{N "}$ \\
\hline & Sig. (2-tailed) & .590 & .688 & .018 & .000 & & .000 \\
\hline & $N$ & 33 & 33 & 33 & 33 & 33 & 33 \\
\hline \multirow[t]{3}{*}{ TotalPEU } & Pearson Correlation & $.546^{\star \star}$ & $.459^{n \pi}$ & $.795^{\times \star}$ & $.694^{\mathrm{N}}$ & $.754^{\pi \star}$ & 1 \\
\hline & Sig. (2-tailed) & .001 & .007 & .000 & .000 & .000 & \\
\hline & $N$ & 33 & 33 & 33 & 33 & 33 & 33 \\
\hline
\end{tabular}

*. Correlation is significant at the 0.05 level (2-tailed).

**. Correlation is significant at the 0.01 level (2-tailed).

Dari data output Tabel 1. dapat dilihat bahwa nilai Pearson Correlation dari butir 1 sampai butir 5 berada di atas r-tabel 0.344 dan memiliki tanda bintang dua, artinya hal ini menunjukan bahwa butir tersebut valid dan nilai ini signifikan pada tingkat signifikansi 0,00 .

\section{Perceived Usefulness}

Hasil uji aspek Perceived Usefulness tersaji pada table berikut ini:

Tabel 2. Uji Validitas Perceived Usefulness

\begin{tabular}{|c|c|c|c|c|c|c|}
\hline & & Corre & ons & & & \\
\hline & & $\mathrm{X} 1$ & $\times 2$ & $\times 3$ & $\mathrm{X} 4$ & TotalPU \\
\hline $\mathrm{X} 1$ & Pearson Correlation & 1 & $.660^{\mathrm{m}}$ & $.704^{\star \pi}$ & $.547^{x \times}$ & $.859^{\star \star}$ \\
\hline & Sig. (2-tailed) & & .000 & .000 & .001 & .000 \\
\hline & $\mathrm{N}$ & 33 & 33 & 33 & 33 & 33 \\
\hline $\mathrm{x} 2$ & Pearson Correlation & $.660^{\mathrm{*}}$ & 1 & $.645^{\mathrm{N}}$ & $.374^{\star}$ & $.792^{\star \star}$ \\
\hline & Sig. (2-tailed) & .000 & & .000 & .032 & .000 \\
\hline & $\mathrm{N}$ & 33 & 33 & 33 & 33 & 33 \\
\hline $\mathrm{x} 3$ & Pearson Correlation & $.704^{\mathrm{x}}$ & $.645^{\mathrm{k*}}$ & 1 & $.544^{x \times}$ & $.900^{\star *}$ \\
\hline & Sig. (2-tailed) & .000 & .000 & & .001 & .000 \\
\hline & $\mathrm{N}$ & 33 & 33 & 33 & 33 & 33 \\
\hline $\mathrm{X} 4$ & Pearson Correlation & $.547^{\mathrm{N}}$ & $.374^{*}$ & $.544^{\mathrm{N}}$ & 1 & $.751^{\star \star}$ \\
\hline & Sig. (2-tailed) & .001 & .032 & .001 & & .000 \\
\hline & $\mathrm{N}$ & 33 & 33 & 33 & 33 & 33 \\
\hline TotalPU & Pearson Correlation & $.859^{\mathrm{*}}$ & $.792^{\mathrm{*N}}$ & $.900^{* \pi}$ & $.751^{\star *}$ & 1 \\
\hline & Sig. (2-tailed) & .000 & .000 & .000 & .000 & \\
\hline & $\mathrm{N}$ & 33 & 33 & 33 & 33 & 33 \\
\hline
\end{tabular}

**. Correlation is significant at the 0.01 level (2-tailed)

*. Correlation is significant at the 0.05 level (2-tailed) 
Dari data output Tabel 2. dapat dilihat bahwa nilai Pearson Correlation dari butir 1 sampai butir 4 berada di atas $r$-tabel 0.344 dan memiliki tanda bintang dua, artinya hal ini menunjukan bahwa butir tersebut valid dan nilai ini signifikan pada tingkat signifikansi 0,00 .

\section{Attitude Toward Using}

Hasil uji aspek Attitude Toward Using tersaji pada table berikut ini:

Tabel 3. Uji Validitas Attitude Toward Using

Correlations

\begin{tabular}{|c|c|c|c|c|}
\hline & & $\mathrm{X} 1$ & $\times 2$ & TotalATU \\
\hline \multirow[t]{3}{*}{$\mathrm{X} 1$} & Pearson Correlation & 1 & $.423^{x}$ & $.859^{\star \pi}$ \\
\hline & Sig. (2-tailed) & & .014 & .000 \\
\hline & $\mathrm{N}$ & 33 & 33 & 33 \\
\hline \multirow[t]{3}{*}{$\mathrm{x} 2$} & Pearson Correlation & $.423^{*}$ & 1 & $.828^{n *}$ \\
\hline & Sig. (2-tailed) & .014 & & .000 \\
\hline & $\mathrm{N}$ & 33 & 33 & 33 \\
\hline \multirow[t]{3}{*}{ TotalATU } & Pearson Correlation & $.859^{\prime *}$ & $.828^{\prime *}$ & 1 \\
\hline & Sig. (2-tailed) & .000 & .000 & \\
\hline & $\mathrm{N}$ & 33 & 33 & 33 \\
\hline
\end{tabular}

*. Correlation is significant at the 0.05 level (2-tailed).

**. Correlation is significant at the 0.01 level (2-tailed).

Dari data output Tabel 3 dapat dilihat bahwa nilai Pearson Correlation dari butir 1 sampai butir 2 berada di atas r-tabel 0.344 dan memiliki tanda bintang dua, artinya hal ini menunjukan bahwa butir tersebut valid dan nilai ini signifikan pada tingkat signifikansi 0,00 .

\section{Behavioral Intention of Use}

Hasil uji aspek Behavioural Intention of Use tersaji pada table berikut ini:

Tabel 4 Uji Validitas Behavioural Intention of Use

\begin{tabular}{|c|c|c|c|c|c|c|c|}
\hline \multicolumn{8}{|c|}{ Correlations } \\
\hline & & $\mathrm{X} 1$ & $\times 2$ & $\times 3$ & $\mathrm{X} 4$ & $\times 5$ & TotalBIU \\
\hline \multirow[t]{3}{*}{$\mathrm{X} 1$} & Pearson Correlation & 1 & $.547^{\star \star}$ & .311 & $.585^{\star \star}$ & $.427^{\star}$ & $.756^{\mathrm{k}}$ \\
\hline & Sig. (2-tailed) & & .001 & .078 & .000 & .013 & .000 \\
\hline & $N$ & 33 & 33 & 33 & 33 & 33 & 33 \\
\hline \multirow[t]{3}{*}{$\mathrm{X} 2$} & Pearson Correlation & $.547^{\mathrm{N}}$ & 1 & $.450^{\pi \times}$ & $.452^{\star *}$ & $.589^{* \pi}$ & $.779^{\star \star}$ \\
\hline & Sig. (2-tailed) & .001 & & .009 & .008 & .000 & .000 \\
\hline & $N$ & 33 & 33 & 33 & 33 & 33 & 33 \\
\hline \multirow[t]{3}{*}{$\mathrm{X} 3$} & Pearson Correlation & .311 & $.450^{\star \pi}$ & 1 & .343 & $.537^{\star \star}$ & $.661^{* \pi}$ \\
\hline & Sig. (2-tailed) & .078 & .009 & & .051 & .001 & .000 \\
\hline & $\mathrm{N}$ & 33 & 33 & 33 & 33 & 33 & 33 \\
\hline \multirow[t]{3}{*}{$\mathrm{X} 4$} & Pearson Correlation & $.585^{\star \pi}$ & $.452^{\star \pi}$ & .343 & 1 & $.624^{\star \star}$ & $.792^{\star \star}$ \\
\hline & Sig. (2-tailed) & .000 & .008 & .051 & & .000 & .000 \\
\hline & $\mathrm{N}$ & 33 & 33 & 33 & 33 & 33 & 33 \\
\hline \multirow[t]{3}{*}{$\times 5$} & Pearson Correlation & $.427^{\star}$ & $.589^{\star \pi}$ & $.537^{\star \star}$ & $.624^{\pi \times}$ & 1 & $.844^{\pi \pi}$ \\
\hline & Sig. (2-tailed) & .013 & .000 & .001 & .000 & & .000 \\
\hline & $\mathrm{N}$ & 33 & 33 & 33 & 33 & 33 & 33 \\
\hline \multirow[t]{3}{*}{ TotalBIU } & Pearson Correlation & $.756^{\star \pi}$ & $.779^{\star \pi}$ & $.661^{\star \pi}$ & $.792^{\wedge \pi}$ & $.844^{\star \pi}$ & 1 \\
\hline & Sig. (2-tailed) & .000 & .000 & .000 & .000 & .000 & \\
\hline & $\mathrm{N}$ & 33 & 33 & 33 & 33 & 33 & 33 \\
\hline
\end{tabular}


Dari data output Tabel 4 dapat dilihat bahwa nilai Pearson Correlation dari butir 1 sampai butir 5 berada di atas $r$-tabel 0.344 dan memiliki tanda bintang dua, artinya hal ini menunjukan bahwa butir tersebut valid dan nilai ini signifikan pada tingkat signifikansi 0,00 .

\section{Actual System Usage}

Hasil uji aspek Actual System Usage tersaji pada table berikut ini:

Tabel 5 Uji Validitas Actual System Usage

\begin{tabular}{|c|c|c|c|c|c|c|}
\hline \multicolumn{7}{|c|}{ Correlations } \\
\hline & & $\mathrm{X} 1$ & $\times 2$ & $\times 3$ & $\mathrm{X} 4$ & TotalAU \\
\hline \multirow[t]{3}{*}{$\mathrm{X} 1$} & Pearson Correlation & 1 & $.522^{* \times}$ & $.530^{\mathrm{kx}}$ & $.666^{* *}$ & $.837^{* *}$ \\
\hline & Sig. (2-tailed) & & .002 & .001 & .000 & .000 \\
\hline & $N$ & 33 & 33 & 33 & 33 & 33 \\
\hline \multirow[t]{3}{*}{$\mathrm{X} 2$} & Pearson Correlation & $.522^{\mathrm{kx}}$ & 1 & $.384^{x}$ & $.437^{*}$ & $.722^{\mathrm{N}}$ \\
\hline & Sig. (2-tailed) & .002 & & .027 & .011 & .000 \\
\hline & $\mathrm{N}$ & 33 & 33 & 33 & 33 & 33 \\
\hline \multirow[t]{3}{*}{$\mathrm{X} 3$} & Pearson Correlation & $.530^{* *}$ & $.384^{*}$ & 1 & $.638^{\mathrm{k}}$ & $.812^{\mathrm{N}}$ \\
\hline & Sig. (2-tailed) & .001 & .027 & & .000 & .000 \\
\hline & $\mathrm{N}$ & 33 & 33 & 33 & 33 & 33 \\
\hline \multirow[t]{3}{*}{$\mathrm{X} 4$} & Pearson Correlation & $.666^{* *}$ & $.437^{*}$ & $.638^{\mathrm{*m}}$ & 1 & $.845^{\mathrm{N}}$ \\
\hline & Sig. (2-tailed) & .000 & .011 & .000 & & .000 \\
\hline & $N$ & 33 & 33 & 33 & 33 & 33 \\
\hline \multirow[t]{3}{*}{ TotaIAU } & Pearson Correlation & $.837^{* *}$ & $.722^{* *}$ & $.812^{* *}$ & $.845^{* *}$ & 1 \\
\hline & Sig. (2-tailed) & .000 & .000 & .000 & .000 & \\
\hline & $\mathrm{N}$ & 33 & 33 & 33 & 33 & 33 \\
\hline
\end{tabular}

Dari data output Tabel 5 dapat dilihat bahwa nilai Pearson Correlation dari butir 1 sampai butir 4 berada di atas r-tabel 0.344 dan memiliki tanda bintang dua, artinya hal ini menunjukan bahwa butir tersebut valid dan nilai ini signifikan pada tingkat signifikansi 0,00 .

Hasil uji validitas yang telah dilakukan terhadap kemudahan penggunaan (Perceived Ease of Use), manfaat penggunaan (Perceived Usefullness), sikap pengguna (Atitude Toward Using), keinginan pengguna (Behavioral Intention of Use), kesadaran pengguna (Actual System Usage) menunjukkan bahwa seluruh butir pernyataan (total 20 butir) yang ada memiliki skor validitas di atas r-tabel $(0,344)$, sehingga dapat dinyatakan seluruh butir pertanyaan tersebut valid.

\subsection{Hasil Uji Reliabilitas}

Uji reliabilitas digunakan untuk membuktikan bahwa butir-butir pernyataan dalam kuesioner konsisten atau tidak. Apabila nilai Cronbach Alpha > r-tabel maka butir-butir pernyataan dalam kuesioner tersebut dapat dipercaya atau reliabel. Hasil uji reliabilitas dari kedua secara rinci tersaji pada Tabel 6, 7, 8, 9, 10 berikut: 
Tabel 6 Uji Reliabilitas Perceived Ease of Use

\section{Reliability Statistics}

\begin{tabular}{r|r}
$\begin{array}{c}\text { Cronbach's } \\
\text { Alpha }\end{array}$ & N of Items \\
\hline .674 & 5 \\
\hline
\end{tabular}

\begin{tabular}{|c|c|c|c|c|}
\hline \multicolumn{5}{|c|}{ Item-Total Statistics } \\
\hline & $\begin{array}{l}\text { Scale Mean if } \\
\text { Item Deleted }\end{array}$ & $\begin{array}{c}\text { Scale } \\
\text { Variance if } \\
\text { Item Deleted }\end{array}$ & $\begin{array}{l}\text { Corrected } \\
\text { Item-Total } \\
\text { Correlation }\end{array}$ & $\begin{array}{l}\text { Cronbach's } \\
\text { Alpha if Item } \\
\text { Deleted }\end{array}$ \\
\hline $\mathrm{X} 1$ & 13.36 & 3.426 & .339 & .659 \\
\hline$x_{2}$ & 13.45 & 3.568 & .211 & .705 \\
\hline$\times 3$ & 13.55 & 2.443 & .592 & .536 \\
\hline$\times 4$ & 13.48 & 2.945 & .489 & .597 \\
\hline$\times 5$ & 13.55 & 2.568 & .523 & .575 \\
\hline
\end{tabular}

Tabel 7 Uji Reliabilitas Perceived Usefullness

\section{Reliability Statistics}

\begin{tabular}{r|r}
$\begin{array}{c}\text { Cronbach's } \\
\text { Alpha }\end{array}$ & N of ltems \\
\hline .831 & 4 \\
\hline
\end{tabular}

\begin{tabular}{|c|c|c|c|c|}
\hline & $\begin{array}{l}\text { Scale Mean if } \\
\text { Item Deleted }\end{array}$ & $\begin{array}{c}\text { Scale } \\
\text { Variance if } \\
\text { Item Deleted }\end{array}$ & $\begin{array}{l}\text { Corrected } \\
\text { Item-Total } \\
\text { Correlation }\end{array}$ & $\begin{array}{l}\text { Cronbach's } \\
\text { Alpha if Item } \\
\text { Deleted }\end{array}$ \\
\hline $\mathrm{X} 1$ & 10.00 & 2.875 & .771 & .759 \\
\hline$\times 2$ & 10.15 & 2.883 & .653 & .793 \\
\hline$\times 3$ & 10.33 & 1.979 & .758 & .755 \\
\hline$\times 4$ & 10.24 & 2.814 & .558 & .831 \\
\hline
\end{tabular}

Tabel 8 Uji Reliabilitas Attitude Toward Using

\section{Reliability Statistics}

Cronbach's

Alpha Nof Items

$593 \quad 2$

\section{Item-Total Statistics}

\begin{tabular}{rr|r|r|r} 
& $\begin{array}{c}\text { Scale Mean if } \\
\text { Item Deleted }\end{array}$ & $\begin{array}{c}\text { Scale } \\
\text { Variance if } \\
\text { Item Deleted }\end{array}$ & $\begin{array}{c}\text { Corrected } \\
\text { Item-Total } \\
\text { Correlation }\end{array}$ & $\begin{array}{c}\text { Cronbach's } \\
\text { Alpha if Item } \\
\text { Deleted }\end{array}$ \\
\hline $\mathrm{X} 1$ & 3.45 & .318 & .423 & \\
\hline $\mathrm{X} 2$ & 3.48 & .383 & .423 & \\
\hline
\end{tabular}


Tabel 9 Uji Reliabilitas Behavioral Intention of Use

\begin{tabular}{c|r}
\multicolumn{2}{c}{$\begin{array}{l}\text { Reliability Statistics } \\
\begin{array}{c}\text { Cronbach's } \\
\text { Alpha }\end{array}\end{array}$} \\
\hline N of Items \\
\hline .823 & 5 \\
\hline
\end{tabular}

\begin{tabular}{|c|c|c|c|c|}
\hline \multicolumn{5}{|c|}{ Item-Total Statistics } \\
\hline & $\begin{array}{l}\text { Scale Mean if } \\
\text { Item Deleted }\end{array}$ & $\begin{array}{c}\text { Scale } \\
\text { Variance if } \\
\text { Item Deleted }\end{array}$ & $\begin{array}{l}\text { Corrected } \\
\text { Item-Total } \\
\text { Correlation }\end{array}$ & $\begin{array}{l}\text { Cronbach's } \\
\text { Alpha if Item } \\
\text { Deleted }\end{array}$ \\
\hline $\mathrm{X} 1$ & 12.45 & 3.881 & .587 & .798 \\
\hline $\mathrm{x} 2$ & 12.24 & 4.127 & .660 & .780 \\
\hline$\times 3$ & 12.73 & 4.517 & .512 & .817 \\
\hline $\mathrm{X} 4$ & 12.79 & 3.922 & .662 & .776 \\
\hline$\times 5$ & 12.33 & 3.354 & .702 & .765 \\
\hline
\end{tabular}

Tabel 10 Uji Reliabilitas Actual System Usage

\begin{tabular}{|c|c|}
\hline \multicolumn{2}{|c|}{ Reliability Statistics } \\
\hline $\begin{array}{c}\text { Cronbach's } \\
\text { Alpha }\end{array}$ & $\mathrm{N}$ of Items \\
\hline .823 & 5 \\
\hline
\end{tabular}

\begin{tabular}{|c|c|c|c|c|}
\hline \multicolumn{5}{|c|}{ Item-Total Statistics } \\
\hline & $\begin{array}{l}\text { Scale Mean if } \\
\text { Item Deleted }\end{array}$ & $\begin{array}{c}\text { Scale } \\
\text { Variance if } \\
\text { Item Deleted }\end{array}$ & $\begin{array}{l}\text { Corrected } \\
\text { Item-Total } \\
\text { Correlation }\end{array}$ & $\begin{array}{l}\text { Cronbach's } \\
\text { Alpha if Item } \\
\text { Deleted }\end{array}$ \\
\hline $\mathrm{X} 1$ & 12.45 & 3.881 & .587 & .798 \\
\hline$X_{2}$ & 12.24 & 4.127 & .660 & .780 \\
\hline$\times 3$ & 12.73 & 4.517 & .512 & .817 \\
\hline$\times 4$ & 12.79 & 3.922 & .662 & .776 \\
\hline$\times 5$ & 12.33 & 3.354 & .702 & .765 \\
\hline
\end{tabular}

Dari data output Tabel 6, 7, 8, 9, dan 10 dapat dilihat bahwa nilai Cronbach's Alpha dari butir pertanyaan memiliki nilai diatas nilai $r$ tabel sebesar 0.344 , artinya hal ini menunjukan bahwa butir pertanyaan yang ada tersebut dapat dipercaya atau reliabel.

\subsection{Analisis Deskriptif}

Hasil dari analisis deskriptif data yang telah dilakukan pada aspek Perceived Ease of Use, Perceived Usefullness, Atitude Toward Using, Behavioral Intention of Use, Actual System Usage nilai rata-rata keseluruhan nilai Mean cukup tinggi dengan jumlah responden 33 siswa. Rata-rata nilai mean pada aspek kemudahan penggunaan (Perceived Ease of Use) aplikasi Gamelan AR mendapatkan skor 4.10. Kemudian untuk aspek manfaat penggunaan (Perceived Usefullness aplikasi GamelanAR, rata-rata nilai mean mendapatkan skor 4.08. Rata-rata nilai mean aspek pengguna terhadap sikap pengguna (Atitude Toward Using) aplikasi Gamelan AR mendapatkan skor 4.10. Persepsi pengguna terhadap keinginan pengguna (Behavioral Intention of Use) aplikasi GamelanAR mendapatkan rata-rata nilai mean 4.06. Dan, nilai rata-rata mean yang didapat pada aspek kesadaran pengguna (Actual System Usage) aplikasi Gamelan AR adalah 4.08. 


\section{Kesimpulan}

Berdasarkan hasil analisis data terhadap 33 responden siswa kelas VIIIC, SMP Negeri 5 Purwokerto tentang persepsi pengguna terhadap kemudahan penggunaan (Perceived Ease of Use), manfaat penggunaan (Perceived Usefullness), sikap pengguna (Atitude Toward Using), keinginan pengguna (Behavioral Intention of Use), kesadaran pengguna (Actual System Usage) (TAM) aplikasi GamelanAR, maka dapat disimpulkan bahwa hasil uji validitas masing-masing varibel dinyatakan valid sebab nilai uji masing-masing variabel lebih besar dari nilai r-tabel 0.344 . hasil uji reliabilitas masing-masing varibel nilai rata-rata kuat sehingga butir pertanyaan yang ada tersebut dapat dipercaya atau reliable. Dari hasil analisis deskriptif yang telah dilakukan menunjukkan bahwa aspek kemudahan penggunaan (Perceived Ease of Use) dan aspek pengguna terhadap sikap pengguna (Atitude Toward Using) aplikasi Gamelan AR mendapatkan skor tertinggi 4.10.

\section{Ucapan Terima Kasih}

Terima kasih penulis ucapkan kepada Lembaga Penelitian dan Pengabdian Kepada Masyarakat Universitas Amikom Purwokerto atas dukungan yang diberikan selama penelitian dilakukan.

\section{Daftar Pustaka}

[1] Pramudi, Y. T. C. (2010). Model Pembelajaran Multimedia Seni Gamelan Jawa.

[2] Pramanta, F. D., Rohman, A., \& Kurniawan, M. R. (2017). APLIKASI PEMBELAJARAN ALAT MUSIK DAERAH GAMELAN JAWA BERBASIS TEKNOLOGI REALSENSE. SENTIA 2017, 9.

[3] Franks, M. A. (2017). The Desert of the Unreal: Inequality in Virtual and Augmented Reality. UCDL Rev., 51, 499.

[4] Davis, F. D., \& Venkatesh, V. (1996). A critical assessment of potential measurement biases in the technology acceptance model: three experiments. International journal of human-computer studies, 45(1), 19-45.

[5] Davis, F. D.; Bagozzi, R. P.; Warshaw, P. R. (1989), "User acceptance of computer technology: A comparison of two theoretical models", Management Science, 35 (8): 982-1003.

[6] Creswell, J. W., \& Creswell, J. D. (2017). Research design: Qualitative, quantitative, and mixed methods approaches. Sage publications.

[7] Sugiyono. (2016). Metodologi Penelitian Kuantitatif, Kualitatif, dan R\&D. Bandung: CV Alfabeta.

[8] Kusumah, E. P. (2016). Olah Data Skripsi Dengan SPSS 22. Pangkalpinang, Bangka Belitung: LABKOM FE-UBB. doi:https://doi.org/10.5281/zenodo.1143815

[9] Ghozali, Imam. (2016). Aplikasi Analisis Multivariate Dengan Program IBM SPSS 23. Semarang: Badan Penerbit Universitas Diponegoro

[10] Ferdinand, Augusty. (2014). Metode Penelitian Manajemen. Semarang: Badan Penerbit Universitas Diponegoro. 